\title{
The remarkable development and significance of constitutional protection for intellectual property rights in post-Arab Spring constitutions
}

\author{
Bronwen Jones \\ Lecturer, Newcastle University
}

Prior to the Arab Spring uprisings in 2011, no constitutional protection for intellectual property (IP) existed in the many earlier constitutions of Egypt or Tunisia. It is remarkable and surprising therefore that, in 2014, IP clauses appeared in the post-revolutionary constitutions of both countries. This raises the key question: why add to the existing regulation of IP in this way. Is constitutional protection just another example of the inexorable strengthening of IP rights (IPRs) or could it be a means of constraining them, where necessary, to protect other rights? This article argues that including IP in a constitution may, rather than merely strengthening IP owners' rights, open IPRs up to competition against more fundamental constitutionally protected human rights and, for example, support the prioritization of the right to health. This could be a valid explanation for and potential use of the inclusion of IP in the Egyptian and Tunisian Constitutions.

Keywords: intellectual property, constitutions, constitutional protection, human rights, patents, access to medicines, Islamic law, Egypt, Tunisia, Arab Spring, globalization, postcolonialism

Prior to the Arab Spring ${ }^{1}$ uprisings in 2011, no constitutional protection for intellectual property (IP) existed in the many earlier constitutions of Egypt or Tunisia. It is remarkable and surprising, therefore, that such provisions appeared in the post-revolutionary constitutions of both countries. ${ }^{2}$ These IP clauses seem to be 'part of a general trend towards the constitutionalization of IP protection' ${ }^{3}$ Both Egypt and Tunisia have strong IP traditions ${ }^{4}$ and are founder members of the World Trade Organization (WTO), whose

1. Imed Ben Labidi, 'On Naming Arab Revolutions and Oppositional Media Narratives' (2019) 22(3) International Journal of Cultural Studies 450-64.

2. Article 69 Constitution of the Arab Republic of Egypt 2014, hereafter Egyptian Constitution <https://www.wipo.int/edocs/lexdocs/laws/en/eg/eg060en.pdf >; Article 32 Constitution de la République Tunisienne, 2014, hereafter Tunisian Constitution <https://wipolex. wipo.int/en/text/440322>.

3. A similar clause appears in Article 8 of the Libyan interim Constitutional Declaration of $2011<$ https://www.ndi.org/sites/default/files/Handout\%204\%20-\%20Libya\%20Draft\% 20Interim\%20Constitution.pdf $>$. Libya remains unsettled, with the interim constitution still not approved therefore not considered here. Nevertheless, the proposed clause suggests a 'trend'. 4. Egypt IP Laws and Treaties <https://wipolex.wipo.int/en/legislation/profile/EG>; Tunisia IP Laws and Treaties WIPO Lex <https://wipolex.wipo.int/en/legislation/profile/TN>. 
Agreement on Trade-Related Aspects of Intellectual Property Rights (TRIPS) ${ }^{5}$ requires all WTO members to provide a minimum level of IP protection. TRIPS covers patents, trade marks and copyright among other types of IP. ${ }^{6}$ Egypt and Tunisia had already, well before 2011, amended domestic IP legislation to fulfil these obligations, and even exceeded the minimum standards required. ${ }^{7}$ This raises the key question: why add to existing IP regulation in this way? Is constitutional protection - as it appears - just another example of the inexorable "upward ratchet" ${ }^{8}$ of IP rights 'getting unaccountably stronger and more expansive in their scope', ${ }^{9}$ or potentially a means of constraining them where necessary to protect other rights?

IP rights (IPRs), notoriously, have negatively affected access to medicines and the right to health, by delaying the 'diffusion' of patent-protected technology, whose monopolies now last a minimum of twenty years. ${ }^{10}$ The exorbitant prices made possible by the monopoly grant puts new essential medicines beyond many who need them. ${ }^{11}$ Tellingly, the impact on health led to an amendment of TRIPS, in Article 31 bis (implementing the Doha Declaration and Decision of the WTO General Council on TRIPS and Public Health of August $2003^{12}$ ), which was intended to resolve the problem. Unfortunately this measure proved unwieldy, insufficient and unworkable, and was therefore barely used. ${ }^{13}$ Subsequent bilateral Free Trade Agreements (FTAs) have greatly eroded the goodwill shown at Doha by further strengthening IP owners' rights. ${ }^{14}$ This divergence in the international evolution of IP and health systems has

5. Agreement on Trade-Related Aspects of Intellectual Property Rights, Apr. 15, 1994, Agreement Establishing the World Trade Organization, Annex 1C, 1869 U.N.T.S. 299, 33 I. L.M. 1197 (1994) [hereafter TRIPS].

6. Industrial designs, geographical indications, layout designs of integrated circuits, and undisclosed information (including trade secrets).

7. Mohammed El-Said, 'The Road from TRIPS-Minus, to TRIPS, to TRIPS-Plus: Implications of IPRs for the Arab World' (2005) 8 JWIP 1, 53-65.

8. Susan Sell, 'The Global IP Upward Ratchet, Anti-Counterfeiting and Piracy Enforcement Efforts: The State of Play' (2010) Program of Information Justice and Intellectual Property Research Paper No. 15. American University Washington College of Law, Washington, DC $<$ https://digitalcommons.wcl.american.edu/research/15/>.

9. Graham Dutfield, Intellectual Property Rights and the Life Science Industries (Routledge 2016) 1.

10. Article 33 TRIPS.

11. See among others: Ellen't Hoen et al., 'Patent Challenges in the Procurement and Supply of Generic New Essential Medicines and Lessons from HIV in the Southern African Development Community Region' (2018) JoPPP < https://www.ncbi.nlm.nih.gov/pmc/articles/ PMC6277991/>; Susan K Sell, 'TRIPS and the Access to Medicines Campaign' (2001) 20 WIS INT'L LJ 481; Peter Drahos and John Braithwaite, 'Intellectual Property, Corporate Strategy, Globalisation: Trips in Context' (2001) 20 WIS.INT’L.LJ 451.

12. World Trade Organization, Ministerial Declaration of 14 November 2001, WTO Doc. WT/ MIN(01)/DEC/1, 41 ILM 746 (2002) [hereafter Doha Declaration] <http://www.wto.org/english/ thewto_e/minist_e/min01_e/mindecl_e.htm>.

13. Muhammad Z Abbas and Shamreeza Riaz, "WTO "Paragraph 6" System for Affordable Access to Medicines: Relief or Regulatory Ritualism?' (2018) 21 JWIP 32-51, 45. See also J Wakely, 'Compulsory Licensing under TRIPs: An Effective Tool to Increase Access to Medicines in Developing and Least Developed Countries?' (2011) 33(5) EIPR 299.

14. Henning Grosse Ruse-Khan, 'The International Law Relation between TRIPs and Subsequent TRIPs-Plus Free Trade Agreements: Towards Safeguarding TRIPs Flexibilities' (2011) 18(2) J.Intell.Prop.L. 325. 
led to IPRs compromising consumer welfare ${ }^{15}$ and people's lives. ${ }^{16}$ Responding to the consequent backlash against IP, Ruse-Khan attempted to show how conflict rules could help resolve disputes in favour of prioritizing the right to health, but even he concedes his analysis depends on, 'the willingness and ability of interested FTA parties' and the 'absence of pressure and bullying', ${ }^{17}$ both of which are unlikely. A better means of prioritizing the right to health over IP owners' rights is, therefore, still required, and there is, indeed, evidence of states strengthening the constitutional protection of the right to health. ${ }^{18}$ It could further be, as Geiger suggests, that also including IP in a constitution may, rather than strengthening IP owners' rights, open IPRs to competition against constitutionally protected human rights, thus enabling the prioritization of the right to health. ${ }^{19}$ This potential benefit could be a valid explanation for including IP in the Egyptian and Tunisian Constitutions.

This paper argues, following Geiger's analysis, that introducing IP into the Egyptian and Tunisian constitutions could potentially ensure greater equity in the IP system, consistent with the goals of the Arab Spring revolutions, by providing a better balance of rights between IP owners and consumers whose lives may depend on IPprotected matter. Despite significant differences in the detail of their complex histories, the pairing of Egypt and Tunisia for comparison is justified by similar colonial histories, somewhat similar legal systems, and the synchronicity of the revolutions in both jurisdictions during the Arab Spring, after which both states passed constitutions protecting IP for the first time in 2014. By considering the nature and role of IP in constitutions both historically and in the present, it is possible to reflect on the context in which the Egyptian and Tunisian constitutions were drafted, including the social injustice that led to uprisings in both countries.

This article considers how provisions in the new constitutions could alleviate tensions between IPRs and the right to health, examining the text of the IP clauses, the role of Islamic law (Sharia), and the role of human rights protection. Finally, it examines the alternative approach of South Africa, concluding that achieving a human rights-based solution to access to medicines, where IPRs are a barrier, can occur with or without an IP clause in the constitution. However, it argues that insertion of a constitutional IP clause may be beneficial rather than detrimental in ensuring that more fundamental rights - such as health - are prioritized.

15. Laurence Helfer, 'Human Rights and Intellectual Property: Mapping an Evolving and Contested Relationship' in Rochelle C Dreyfuss and Justine Pila (eds), Oxford Handbook of Intellectual Property Law (OUP 2018) 118.

16. Frederick M Abbott, 'The Doha Declaration on the TRIPS Agreement and Public Health and the Contradictory Trend in Bilateral and Regional Free Trade Agreements' (27 December 2011), Quaker United Nations Office (Geneva), Occasional Paper No. 14, April 2004, 12 $<$ https://quno.org/sites/default/files/resources/TRIPS-Public-Health-FTAs.pdf>.

17. Ruse-Khan (n 14) 365.

18. SK Perehudoff, B Toebe and H Hogerzeil, 'Essential Medicines in National Constitutions: Progress Since 2008' (2016) 18(1) HHR 142; Eleanor D Kinney and Brian Alexander Clark, 'Provisions for Health and Health Care in the Constitutions of the Countries of the World' (2004) 37(2) Cornell ILQ 285-355 <http://scholarship.law.cornell.edu/cilj/vol37/iss2/2>.

19. Christophe Geiger, "Intellectual "Property" after the Treaty of Lisbon: Towards a Different Approach in the New European Legal Order' (2010) 32(6) EIPR 255; Christophe Geiger, 'Freedom of Expression as an External Limitation to Copyright Law in the EU: The Advocate General of the CJEU Shows the Way' (2019) 41(3) EIPR 131. 


\section{THE INTERNATIONAL FRAMEWORK FOR IP PROTECTION}

The starting point for understanding the strengthening of IP protection in Egypt and Tunisia, and understanding the purpose of constitutional protection is the TRIPS Agreement, which was attached to the WTO agreement at the behest of lobby groups in the more powerful countries, especially the US. ${ }^{20}$ TRIPS from its inception has been controversial. The ex-President of the Egyptian Association for the Protection of Industrial Property explained that she had "no doubt that TRIPS is much more in favour of developed countries than developing countries'. ${ }^{21}$ Criticized as having 'the transparency of a one-way mirror', ${ }^{22}$ the negotiations leading to the TRIPS Agreement were opaque and nakedly political. ${ }^{23}$ Viewed differently by developed and developing countries, IP proponents considered TRIPS to be a 'floor, not a ceiling' ${ }^{24}$ with the expectation of ever-increasing protection. Advice given to developing countries to make maximum use of flexibilities within the TRIPS agreement ${ }^{25}$ has been, therefore, only a temporary fix, with such flexibility soon eroded. Pro-IP lobbyists representing firms with 'global reach and extensive IP portfolios [which] stood to gain staggering amounts of licensing revenue if their processes and products were better protected', ${ }^{26}$ pushed for the strongest possible protection. US companies can charge whatever the market will bear for their inventions regardless of the technological subject matter. IP-protected inventions in the health sector are treated no differently than a 'toaster', ${ }^{27}$ and US Pharma continues to lead the 'increasingly vocal IP lobby' ${ }^{28}$ for raising IP standards. With most Pharma based in the Global North, the resulting revenue accrues to those jurisdictions. ${ }^{29}$

IP law is, as Helfer and Austin explain, 'generally agnostic about both the static and the dynamic distributional consequences of monopoly pricing structures' ${ }^{30}$ Hepatitis $\mathrm{C}$ drug, sofosbuvir (brand name Sovaldi), for example, was priced at $\$ 1000$ per pill, $\$ 84000$ for the potentially curative 12 -week course, a price described as 'extraordinary', ${ }^{31}$ which brought the company, Gilead, a 'record-smashing \$2.3 billion during the first quarter

20. Susan K Sell, Private Power, Public Law: The Globalization of Intellectual Property Rights (CUP 2003) 38.

21. Hoda Serageldine, President of the Egyptian Association for the Protection of Industrial Property (AEPPI), Managing Partner Saba \& Co. IP, Personal Interview, Garden City, Cairo, Egypt, January 2010.

22. Peter Drahos and John Braithwaite, Information Feudalism: Who Owns the Knowledge Economy (Routledge 2002) 138.

23. Susan K Sell, 'TRIPS and the Access to Medicines Campaign (2001) 20(3) Wis.Int'1 L.J. 3 481, 482; DM Nachane, 'Intellectual Property Rights in the Uruguay Round: An Indian Perspective' (1995) 30 EPW 5, 257-68.

24. Sell (n 8).

25. Ruse-Khan (n 14).

26. Sell (n 20) 38.

27. David Vaver and Shamnad Basheer, 'Popping Patented Pills: Europe and a Decade's Dose of TRIPs' (2006) 28(5) EIPR 282, 291.

28. Sell (n 20) 48.

29. 'The World's Biggest Pharmaceutical Companies by Revenue in 2018' Pharmaceutical Technology <https://www.pharmaceutical-technology.com/features/worlds-biggest-pharmaceuticalcompanies-2018/>.

30. Laurence Helfer and Graeme Austin, Human Rights and Intellectual Property Law (CUP 2011) 521.

31. Melanie Senior, 'Sovaldi Makes Blockbuster History, Ignites Drug Pricing Unrest' (2014) 32 Nat.Biotechnol. 501-2. 
of 2014' ${ }^{32}$ However, Egypt, with the greatest incidence of Hepatitis C worldwide, has already proved adept at using TRIPS flexibilities and has utilized domestic IP law to make key medicines accessible in this case by refusing a patent to sofosbuvir on grounds of lack of novelty and inventiveness. ${ }^{33}$ This allowed generic equivalents to be sold in Egypt for US\$120 for the 12-week course. ${ }^{34}$ As a result, studies have concluded that 'the availability of generic drugs in Egypt will help much in eradication of the virus'. ${ }^{35}$ Egypt's successful public health campaign is considered an exemplar for other countries, including developed countries, in managing public health issues. ${ }^{36}$ For this approach to continue to succeed, however, requires countries to resist pressure to further reduce TRIPS flexibilities. Constitutional protection for IP should support such an approach and help underline the importance of prioritizing health.

\section{CONSTITUTION DRAFTING AND THE HISTORICAL DEVELOPMENT OF IP}

The inclusion of IP as a constitutional principle dates to the drafting of the foundational constitution of the United States of America (US), written in 1787 and still in force. ${ }^{37}$ What inspired the drafters of the Egyptian and Tunisian constitutions to do the same in 2014 ?

Written constitutions are common in all types of jurisdiction, including civil, common and Islamic law. The very few exceptions include the UK. Drafting a written constitution may happen through different circumstances: codification for the first time of an un-codified constitution or to establish an independent state following decolonization, which was the case for Egypt and Tunisia in 1936 and 1959 respectively. ${ }^{38}$ Since the nineteenth century, Egypt and Tunisia have drafted constitutions embodying Monarchist, Socialist, Liberal, Democratic, and Islamic principles, but none has referred to IP until the 2014 constitutions.

A constitution is widely thought to embody the spirit of a nation, which is inevitably a simplification. 'Constitutions routinely bear the stamp of the interests of the actors who created them.' ${ }^{39}$ In reality, the framers are individuals, usually drawn entirely from an

32. Ibid.

33. Heba Wanis, 'No Sofosbuvir Patent in Egypt, but Gilead Deal Still Expensive' (2014) TWN <https://www.twn.my/title2/health.info/2014/hi140402.htm>.

34. Ellen't Hoen, 'The Power of TRIPS Flexibilities in Medicines Procurement' (2018) Medicines Law \& Policy <https://medicineslawandpolicy.org/2018/04/the-power-of-tripsflexibilities-in-medicines-procurement/>.

35. Sherief Abd Elsalam et al., 'Sofosbuvir Plus Daclatasvir in Treatment of Chronic Hepatitis C Genotype 4 Infection in a Cohort of Egyptian Patients: An Experiment the Size of Egyptian Village' (2018) Int.J.Hepatol. <https://www.hindawi.com/journals/ijh/2018/9616234/>.

36. Ted Alcorn, 'Why Egypt Is at the Forefront of Hepatitis C Treatment' (2018) The Atlantic $<$ https://www.theatlantic.com/health/archive/2018/05/why-egypt-is-at-the-forefront-of-hepatitisc-treatment $/ 561305 />$.

37. United States of America (US Const.) 17th September 1787 Section 1(8)(8).

38. Constitutions in both Egypt and Tunisia existed both before and after those dates. Tunisian Constitutions date from the mid-nineteenth century, before the French occupation of Tunisia in 1882. See Nathan Brown, Constitutions in a Nonconstitutional World: Arab Basic Laws and the Prospects for Accountable Government (SUNY Press 2002) especially 91-4.

39. Ester Cross and Jason Sorensen, 'Arab Spring Constitution-Making: Polarization, Exclusion, and Constraints' (2016) 23(7) Democratization 1292-312, 1294. 
elite, whose input owes more to their exceptionalism than any representative capacity. Perhaps the elite capture their own spirit, while others remain on the periphery, dependent on the framers' goodwill for protection of their interests. The drafters' influences and motivations are therefore important, as well as who is included or excluded. Scrutiny of special interests' influence on the drafting process would be revealing, too. ${ }^{40}$ However, such detail is typically unavailable, and even with best practice the process of constitution-making is obscure. The language used and complexity of discourse mean, without specialist knowledge, 'distinguishing among passion, private interest, and public reason is not easy'. ${ }^{41}$ Indeed, it is partly the arcane nature of IP that has aided its successful promotion. Law makers and health activists may not have fully appreciated the implications of extending IP protection until too late. ${ }^{42}$

Constitutions tend not to be entirely original, with inevitable overlap where functions are common to all systems. Egyptian and Tunisian drafters will have been aware of the developmental role IP has seemingly played in industrialized countries. They would also have known of IP developments in developing countries, including South Africa, a jurisdiction which has figured prominently in IP and access to medicines. ${ }^{43}$ South Africa has, more recently than Egypt and Tunisia, emerged from colonialism through the ending of apartheid. The experience of colonialism has effects that linger, continuing to inform postcolonial developments, leading to suspicion of "wholesale importation of foreign approaches'. ${ }^{44}$ Like other developing countries, Egypt and Tunisia are alert to power imbalance in the international system.

Following war or revolution there is an opportunity and a need to re-establish the priorities of a nation and re-distribute power. The constitution-writing process is relaunched to replace the discredited system. In such circumstances it is normal practice to consider other constitutions, especially when introducing new concepts. The drafters' choice to include IP protection in the post-Arab Spring constitutions of 2014 will have been carefully considered, and made on perceived benefits. These should accrue to Egyptian and Tunisian citizens and address the revolutionary goals.

IPRs evolved as exceptions to free trade, meaning, where patents are concerned, that the right owner can prevent others from 'making, using, offering for sale, selling or importing' the protected material; ${ }^{45}$ although IP subject matter is so disparate the rights are now collectively referred to as intellectual property due to their intangible nature and connection with invention and creativity. Early forms of patent were notoriously royal grants to reward favourites and could be for anything at all, creative or not. ${ }^{46}$ These monopolies gave patent owners great economic power and potential for excessive exploitation. Consequently, Sir Edward Coke defined and limited the only valid use of a patent as being for an invention ... that never was used before, ... for the

40. Mark Tushnet, 'Some Skepticism about Normative Constitutional Advice' (2008) 49 W.M.L.R. 1473; IM Hartshorn, 'Organized Interests in Constitutional Assemblies: Egypt and Tunisia in Comparison' (2017) 70(2) Polit.Res.Q. 408-20, 418.

41. N Brown, 'Reason, Interest, Rationality, and Passion in Constitution Drafting' (2008) 6(4) Perspectives on Politics 675-89, 679; Hartshorn (n 40).

42. Sell (n 23) 483.

43. Ellen't Hoen, 'TRIPS, Pharmaceutical Patents, and Access to Essential Medicines: A Long Way from Seattle to Doha' (2002) 3 CJIL 27.

44. Donna E Arzt, 'The Application of International Human Rights Law in Islamic States' (1990) 12 HRQ 202, 227.

45. Article 28 TRIPS.

46. Darcy v Allin (or Allen) (1559) 74 ER 1131; Christine Macleod, 'The 1690s Patents Boom Invention or Stock-Jobbing?' (1986) 39(4) Econ.Hist.Rev. 549-71, 550. 
good of the realm'. Modern patent law, therefore, evolved to prevent abuses, promote free trade, and incentivize inventors to create. However, the idea of property is 'tremendously dynamic' ${ }^{47}$ In propertizing the subject matter, and departing from the idea of IP as privilege, the rights granted have been greatly strengthened, causing serious concerns regarding overprotection in the international IP regime.

In 1623, the English parliament asserted authority over the monarch by limiting patent monopolies to those for, 'the sole working or makinge of any manner of new Manufactures within this Realme, to the true and first Inventor and Inventors of such Manufactures'. ${ }^{48}$ All other monopolies were abolished. Thus, England introduced a patent law system earlier than other jurisdictions, although the principle of issuing patents was more widely practised ${ }^{49}$ Copyright law was introduced later, following the English Civil War, expressly 'for the encouragement of learning' and to 'encourage learned men to compose and write useful books'. IPRs were exceptional time-limited monopolies granted by statute for specific purposes. They were justified by public benefit. The corollary is that they are not justified without such benefit. In the US Constitution IP protection is explicitly utilitarian, 'to promote the Progress of Science and useful Arts'. ${ }^{50}$ It should also, perhaps, have expressly included the proviso that it should do no harm. Constitutional protection of IP in Egypt and Tunisia should be a moderating influence capable of ensuring the prevention of harm. If IPRs impede access to fundamental rights such as health through the unavailability of essential medicines, the strength of right granted is inappropriate and should be challenged.

El-Said, among many others, is concerned about the overprotection of IP, which 'is likely to have direct impact on the availability and affordability of medicines and access to knowledge and education'. ${ }^{51}$ For IP law to enjoy legitimacy in the Arab world postArab Spring, it must demonstrate such a benefit. Unfortunately, the international IP regime has evolved with health a secondary consideration, progressively strengthening IPRs due to their high value advantaging the most developed countries.

Intellectual property purportedly contributed to the development of the most powerful modern economies, but its historical roots are complex. In the UK, IP evolved with the industrial revolution, which empowered and fuelled British colonialism. On achieving independence from Britain after the American Revolution, the framers of the US foundational constitution were apparently influenced in their decision to include IP by its perceived role in driving British power and economic success. ${ }^{52}$ They may have been misguided, if patents truly 'played no major role ... during Britain's Industrial Revolution'. ${ }^{53}$ Nevertheless, IP law was 'extended to the colonies by the

47. Paul Steidlmeier, 'The Moral Legitimacy of Intellectual Property Claims: American Business and Developing Country Perspectives' (1993) 12 Journal of Business Ethics 157-64, 158.

48. An Act concerning Monopolies and Dispensations with Penal Laws and the Forfeitures thereof, 1624, 21 Jac.I, c.3 (1624).

49. MLF Nascimento and ED Zanotto, 'On the First Patents, Key Inventions and Research Manuscripts about Glass Science and Technology’ (2016) 47 World.Pat. 54-66, 58.

50. US Const. Section 1(8)(8).

51. Mohammed El-Said, 'The Implementation Paradox: Intellectual Property Regulation in the Arab World' (2010) 9(3) J.I.T.L. 3 221-35, 227.

52. Edward C Walterscheid, 'To Promote the Progress of Science and Useful Arts: The Background and Origin of the Intellectual Property Clause of the United States Constitution' (1994) 2 J.Intell.Prop.L. 1, 14.

53. Petra Moser, 'Patents and Innovation: Evidence from Economic History' (2013) 27 JEP $23-44,25$. 
English laws, ${ }^{54}$ and existed in some US states prior to unification. Practices differed, however, so centralization of legislative power in federal government was necessary to harmonize IP law across the US. The framers aimed to 'insert essential principles only' and 'use simple and precise language'. ${ }^{55}$ The IP clause was, in these terms, considered essential, and included, according to Walterscheid, as a means of delegating the authority to legislate. ${ }^{56}$

A similar motivation explains IP provision in the ill-fated constitution of the EU, ${ }^{57}$ which as a sui generis state-like organization aims, like the US, to harmonize IP among member states. IP law has traditionally been territorial, enabling states to individually determine the strength of protection offered, in order to capture any benefit locally. Although the EU ultimately failed to approve its proposed written constitution, many of its provisions, including that protecting IP, were included in the EU Charter on Fundamental Rights (EUCFR) ${ }^{58}$ All EU states are bound by the provision in the EUCFR. Contrastingly, in Egypt and Tunisia in 2014, neither harmonization among states, nor the need to empower the national government to legislate was at issue. The fact that Egypt and Tunisia have promulgated multiple iterations of IP legislation since independence, without a constitutional provision, provides evidence for its irrelevance in this respect. Therefore, there must be another purpose for including IP in their 2014 constitutions.

\subsection{Post-Arab Spring: what can constitutionalizing IP contribute?}

The Arab Spring series of revolutionary protests whereby people rose up against repressive and corrupt governments, in some cases overthrowing regimes, has been dubbed 'revolutions in a slow cooker', ${ }^{59}$ because they expressed cumulated frustration over long years of powerlessness. This 'disaffection and anger ... was a stark reminder of what may happen when states abandon commitments to public welfare' ${ }^{60}$ Abdelrahman explains that 'a revolution is a long process ... not one grand moment' ${ }^{61}$ The process is ongoing and has expanded to include other states in the region.

Beginning in Tunisia, in late 2010, protests spread to Egypt in January 2011, then to other areas where citizens identified with the complaints voiced. These included the state exercise of arbitrary power and random violence; ${ }^{62}$ a lack of opportunity (including employment opportunities and opportunities to progress); ${ }^{63}$ violations of rights; ${ }^{64}$

54. Karl Fenning, 'The Origin of the Patent Clause of the US Constitution' (1929) 11 J.Pat. Off. 438, 444.

55. Edmund Randolph cited in Walterscheid (n 52) 32.

56. Walterscheid (n 52) 33.

57. Article 17 EU Draft Treaty Establishing a Constitution for Europe (not ratified),

16 December 2004, OJ-C310, 16 December 2004.

58. Article 17 EUCFR, 26 October 2012, 2012/C 326/02.

59. Ebrahim Moosa, 'Aesthetics and Transcendence in the Arab Uprisings' (2011) 3 MELG $171-80,172$.

60. Lisa Anderson, 'Bread, Dignity and Social Justice: Populism in the Arab World' (2018) 44(4) Philos.Soc.Critic. 478-90, 479.

61. Maha Abdelrahman, Egypt's Long Revolution: Protest Movements and Uprisings (Routledge 2015).

62. Anderson (n 60) 485.

63. Adeel Malik and Bassem Awadallah, 'The Economics of the Arab Spring' (2013) 45 World.Dev. 296-313, 296.

64. Anderson (n 60) 485. 
and desperately poor living conditions for the vast majority of citizens, who lacked even the basic requirements for a decent life, feeling 'state failure in all spheres of their lives' ${ }^{65}$ Indeed, the conditions that provoked the 2011 revolutions remain little changed, and 'the real struggle for change in the Arab World will only begin when the dust from its youth revolutions has finally settled'. ${ }^{66}$ It is clear that 'careful consideration of the public interest' will be 'fundamental for successful decision-making and policy-setting.' ${ }^{67}$ Whether including IP in the post-revolution constitutions will contribute positively in this respect is still unclear. A recent study suggests that strengthening IP laws is good for developed countries but for developing countries there is at best an insignificant effect and it is more likely to be negative. Countries with 'lower levels of sophistication and low levels of human capital' may be unable to surmount the damaging effects of IPRs. ${ }^{68}$ Thus, increasing IP protection is not guaranteed to have the much-vaunted developmental effects. However, including IP in the Constitution may mitigate some of the negative effects, such as excessive pricing of essential medications, through a human rights balancing test that prioritizes the right to health over IP owners' rights.

\subsection{The roots of the revolutions and hopes for the future}

The revolutions should be seen as on-going and developing events in response to injustice and inequality. In Egypt, immediately prior to the revolution, 'four of the ten richest Africans were Egyptians but one quarter of the entire population, and more than half the population of Upper Egypt lived in dire poverty'. ${ }^{69}$

In Tunisia, although rated highly according to development measures, long-term economic failures 'manifested in a failure to create jobs or deliver inclusive and sustainable growth within a social, political, and economic system dominated by a small coterie of elites'.70

Large parts of the populations of both Egypt and Tunisia have been excluded from basic rights, including the right to health. ${ }^{71}$ After long deprivation, in 2011 the people had simple demands: Bread, Freedom, Social Justice, and Human Dignity. ${ }^{72}$ It is against the fulfilment of these fundamental rights that we should judge the postArab Spring phase. Intellectual property protection should support, rather than impede, the achievement of these goals.

65. Solava Ibrahim, 'A Tale of Two Egypts' (2011) 32(7) TWQ 1347-68, 1349.

66. Malik and Awadallah (n 63) 296.

67. Mohammed El-Said, 'The Morning After: TRIPS-Plus, FTAs, and Wikileaks - Fresh Insights on the Implementation and Enforcement of IP Protection in Developing Countries' (2012) 28 Am.U.Int'l.L.Rev.71-104, 104.

68. Cassandra Mehlig Sweet and Dalibor Sacha Eterovic Maggio, 'Do Stronger Intellectual Property Rights Increase Innovation?' (2015) 66 World.Dev. 665-77, 674.

69. Robert Springborg, Egypt (Polity 2018).

70. Larbi Sadiki, 'The Consequences of Multiple Marginalizations' Policy Briefing Brookings Doha Centre, January 2019, Regional Development in Tunisia, $8<\mathrm{https}: / /$ www.brookings.edu/ wp-content/uploads/2019/01/Regional-development-in-Tunisia-the-consequences-of-multiplemarginalization_English-Web.pdf >.

71. Soha Bayoumi, 'Health in the Time of Revolution: What Role for Health Demands in the Egyptian Uprising?' Princeton-AUB Conference: After the Uprisings <https://www.academia. edu/23326852/Health_in_the_Time_of_Revolution_What_Role_for_Health_Demands_in_the Egyptian_Uprising $>$.

72. See eg Anne Alexander and Mostafa Bassiouny, Bread, Freedom, Social Justice: Workers and the Egyptian Revolution (Zed Books 2014). 


\section{POSTCOLONIAL EFFECTS ON DEVELOPMENT}

The roots of the revolutions run deep, with external as well as internal dimensions. Both Tunisia, under French, and Egypt under British rule experienced the terrible and long-lasting effects of colonialism and, since independence, both countries have experienced 'uneven postcolonial development' ${ }^{73}$ entrenching inequality and injustice. Development stalled in Egypt following the colonial period, despite a substantial industrialization programme. ${ }^{74}$ In Tunisia, a similar profile ${ }^{75}$ ended in crisis, with riots over food prices in $1984 .^{76}$ The reasons for this are multiple (and outside the scope of this paper) but 'massive accumulation of debt' ${ }^{77}$ led both Egypt and Tunisia to resort to borrowing from the International Monetary Fund (IMF) of the World Bank (WB) in the 1980 s and $1990 \mathrm{~s},{ }^{78}$ in the critical period leading up to WTO-TRIPS.

IMF support was conditional on a restructuring programme, which has been partially responsible for further widening inequality, ${ }^{79}$ a driving cause of the 2011 revolutions. Both countries were lauded as 'success stories' following their structural adjustment programmes (SAPs), with Tunisia hailed as the most successful reformer in the Arab World. ${ }^{80}$ However, economic recovery was only partial and 'insufficient attention [was] paid to the social problems, most notably unemployment and inequality, exacerbated by SAPs' ${ }^{81}$ These effects have had enduring consequences, being 'cumulative and self-perpetuating'. ${ }^{82}$ In Egypt, withdrawal of subsidies benefitting the poor, which the IMF insisted upon, had an impact described by the lead economist of the World Bank as 'difficult to estimate'. ${ }^{83} \mathrm{He}$ acknowledged, however, that the effect 'must have been substantial' ${ }^{84}$ In Tunisia he explained, 'the poor could not be protected from the overall price increases brought about by reforms and the subsequent reduction in caloric intake'. ${ }^{85}$ Such an approach is typical of neo-liberal

73. Sadiki (n 70) 6.

74. See eg Richard H Adams Jr, 'Evaluating the Process of Development in Egypt, 1980-97' (2000) 32 Int.J.Middle.East.Stud 255-275, 272; Timothy Mitchell, 'No Factories, No Problems: The Logic of Neo-liberalism in Egypt' (1999) 26(82) ROAPE 455-68, 457.

75. John Waterbury, 'The State and Economic Transition in the Middle East and North Africa' in Nemat Shafik (ed), Prospects for Middle Eastern and North African Economies: From Boom to Bust and Back? (Palgrave 1998) 162.

76. Bradford Dillman, 'The Political Economy of Structural Adjustment in Tunisia and Algeria' (1998) 3 J.N.Afr.Stud. 1-24, 3.

77. MW Daly, The Cambridge History of Egypt Vol II: Modern Egypt from 1517 to the End of the Twentieth Century (CUP 1998).

78. Toby Dodge, 'After the Arab Spring: Power Shift in the Middle East? From the "Arab Awakening" to the Arab Spring; The Post-colonial State in the Middle East' (2012) IDEAS Reports, ed Nicholas Kitchen, LSE, 8.

79. Karen Pfeiffer, 'How Tunisia, Morocco, Jordan and even Egypt became IMF "Success Stories" in the 1990s' (1999) MERIP 23-27, 23.

80. Ibid, 23.

81. Ibid.

82. Willem van Eeghen, 'Poverty in the Middle East and North Africa' in Nemat Shafik (ed), Prospects for Middle Eastern and North African Economies: from Boom to Bust and Back? (Palgrave 1998).

83. Ibid.

84. Ibid, 234.

85. Ibid. 
neglect of the 'actual concerns of any concrete local or collective community', ${ }^{86}$ meaning negative effects are barely explored. Negative effects of IP reforms may have been similarly glossed over.

\subsection{Globalization: connecting trade with intellectual property}

Arguments in favour of globalising IPRs have long been described as 'anything but persuasive [... and potentially] an obstacle to development' 87 'Organized hypocrisy' was evident from the very beginning, with the rhetoric of 'law-based bargaining' in reality a cover for the 'powerful states [which] dominated agenda setting, and rounds'. ${ }^{88}$ Ultimately, states with 'weaker bargaining-power' accepted an agreement potentially contrary to their own 'developmental priorities'. ${ }^{89}$

Developing countries like Egypt and Tunisia hoped joining the WTO would mean more evenly balanced trading conditions, although it has been described as a 'Hobson's choice', ${ }^{90}$ with the negotiating history described as a 'battle between unequals' ${ }^{91}$ Nevertheless, Egypt joined the earlier GATT ${ }^{92}$ Agreement in 1970, with Tunisia following in 1990. Both were WTO members from the outset. As a rule-based rather than power-based organization it promised to provide a fairer trading framework than GATT $1947 .{ }^{93}$ It offered increased export opportunities, but also greatly increased IP protection.

Some IP experts and advisers aware of the potential negative effects strongly opposed signing the agreement, ${ }^{94}$ but trade negotiators saw advantages despite the "essential asymmetries'. ${ }^{95}$ The transplantation of foreign IP laws as a consequence of adopting TRIPS was done, therefore, without any impact assessment or 'scrutiny for their effects on the process of knowledge acquisition, absorption and diffusion' ${ }^{96}$ Not only did this mandate significantly increase IP protection but, crucially, administration of the new global minimum IP standards fell under the WTO's compulsory tribunal, ${ }^{97}$ rather than the

86. Timothy Mitchell, 'No Factories, No Problems: The Logic of Neo-Liberalism in Egypt' (1999) 26(82) Rev.Afr.Polit.Econ. 455-68, 455.

87. See Peter Drahos and Ruth Mayne (eds), Global Intellectual Property Rights (Oxfam 2002) 1.

88. Richard Steinberg, 'In the Shadow of Law or Power? Consensus-Based Bargaining and Outcomes in the GATT/WTO' (2002) 56(2) Int.Organ. 339-74, 365.

89. Basheer (n 88) 20.

90. Nachane (n 23) 266.

91. Shamnad Basheer, 'Trumping TRIPS: Indian Patent Proficiency and the Evolution of an Evergreening Enigma' (2018) 18(1) OUCLJ 16-45, 20.

92. General Agreement on Tariffs and Trade, Oct. 30, 1947, 61 Stat. A-11, 55 U.N.T.S. 194 [hereafter GATT].

93. 'The WTO is Born: Marrakesh Ministerial Meeting' (May 1994) GATT Newsletter 107 $<$ https://docs.wto.org/gattdocs/q/GG/GATTFOCUS/107.pdf>.

94. See eg Carolyn Deere, The Implementation Game (OUP 2009) 56; Ahmed Abdel-Latif, 'Egypt's Role in the A2K Movement: An Analysis of Positions and Practices', in Nagla Rizk and Lea Shaver (eds), Access to Knowledge in Egypt (Bloomsbury Academic 2010) 28.

95. Diana Tussie and Cintia Quiliconi, 'The World Trade Organization and Development' in Bruce Currie-Alder et al. (eds), International Development: Ideas, Experience and Prospects (OUP 2014) 821.

96. Ezieddin Elmahjub, 'Situating Intellectual Property Policy into a Human Development Paradigm' (2015) 18(5) JWIP 245, 255.

97. Dispute Settlement Rules WTO Agreement, Annex 2, 1869 U.N.T.S. 401, 33 I.L.M. 1226 (1994) [DSU]. 
World Intellectual Property Organization (WIPO). This brought the real threat of TRIPS breaches triggering proceedings, ${ }^{98}$ with potential serious consequences including trade sanctions. ${ }^{99}$

\subsection{Post-TRIPS: increasing standards bilaterally while reducing flexibility}

After TRIPS, there was no multilateral appetite for higher IP standards. The EU and the US, however, focused on bilateral methods to press for stronger IP protection using FTAs. Consequently, both Egypt and Tunisia committed to Euro-Mediterranean Association agreements, ${ }^{100}$ with TRIPS-Plus requirements eroding the flexibilities of TRIPS. ${ }^{101}$

Jordan's early experience of a US FTA with TRIPS-Plus provisions illustrates its 'noticeable impacts on many development-related areas'. ${ }^{102}$ Furthermore, Oxfam very negatively reviewed its effect on public health and access to medicines. ${ }^{103}$ Subsequently, El-Said suggested that it would be necessary to demonstrate to Egyptians and Tunisians the economic and social benefits of IPRs for them to be fully accepted instead of being seen 'as a tool of western dominance'. ${ }^{104}$ For this to happen IP policies and rules need proper scrutiny, and must demonstrably respect human rights.

Although discussions surrounding FTAs are usually secret, ${ }^{105}$ the true extent of US and EU machinations was revealed through Wikileaks, and examined by El-Said in the case of Jordan. ${ }^{106}$ The revelations confirm and raise further suspicion regarding US and EU motivations. More than ten years later, following the Arab Spring, ElSaid hopes for a change of approach to intellectual property policy-making, ${ }^{107}$ and this may 'strengthen the legitimacy of the legal framework and its public acceptance'. ${ }^{108}$

In keeping with multinational and bilateral agreements, both Tunisia and Egypt have consistently implemented domestic IP legislation to meet relevant IP requirements. ${ }^{109}$ They have also attempted to utilize the opportunities for flexibility offered by

98. Ibid.

99. Article 3(7) DSU.

100. Egypt-Euro-Mediterranean Association Agreement <https://www.consilium.europa.eu/en/ documents-publications/treaties-agreements/agreement/?id=2001033> .

101. El-Said (n 67) 12.

102. El-Said (n 67) 10; Mohammed El-Said, 'Public Health Related TRIPS-Plus Provisions in Bilateral Trade Agreements: A Policy Guide for Negotiators and Implementers in the WHO Eastern Mediterranean Region' (2010) WHO \& International Centre for Trade and Sustainable Development <http://applications.emro.who.int/dsaf/dsa1081.pdf>.

103. Mohammed El-Said, 'All Costs No Benefits: How the US-Jordan FTA Affects Access to Medicines' (21 March 2007) Oxfam Briefing Paper, Oxfam International <http://www.oxfam. org/en/policy/bp102_jordan_us_fta>.

104. Mohammed K El-Said 'The European TRIPS-Plus Model and the Arab World: From Co-Operation to Association - A New Era in the Global IPRS Regime?' (2007) 28 Liverpool L.R. $143-74$ at 173.

105. William J Katt Jr, 'The New Paper Chase: Public Access to Trade Agreement Negotiating Documents' (2006) 106 Colum.L.Rev 679.

106. El-Said (n 67).

107. Ibid.

108. Christophe Geiger and Elena Izyumenko, 'Freedom of Expression as an External Limitation' (2019) 41(3) EIPR 131, 137.

109. El-Said (n 103). 
TRIPS, which provides for exceptions ${ }^{110}$ and exclusions, ${ }^{111}$ as well as compulsory licensing in certain circumstances. Bilateral agreements such as the EUMediterranean Association agreements undermine some of this flexibility, making it difficult to manage potentially damaging effects using internal IP rules. Correa warns that, 'accepting those standards ... will limit the capacity of States to progressively realize the human right to health'. ${ }^{112}$ Tunisia entered into a Trade and Investment Framework Agreement (TIFA) with the US in 2002, which envisages further agreements on IP, ${ }^{113}$ and a Science and Technology Agreement in 2014. ${ }^{114}$ Tunisia is, further, in EU negotiations for a Deep and Comprehensive Free Trade Area (DCFTA) to bring 'the Tunisian legislation closer to that of the EU in traderelated areas'. ${ }^{115}$ This is likely again to raise IP standards. If IPRs clash with health imperatives, constitutional IP protection could ensure human rights have more weight.

\section{THE SIGNIFICANCE OF CONSTITUTIONALLY PROTECTING IP}

As a constitutional right IP must be weighed against other more fundamental rights, in particular the right to health. The Tunisian Constitution states, 'Health is a right for every human being'; ${ }^{116}$ the Egyptian Constitution, 'Every citizen is entitled to health and to comprehensive health care with quality criteria'. ${ }^{117}$ Furthermore, in the Egyptian Constitution, 'denying any form of medical treatment to any human in emergency or life-threatening situations is a crime'. ${ }^{118}$ Where IP and the right to health clash, constitutional protection for IP can help provide equitable outcomes. Schovsbo shows how the constitutionalization of IP operates on the one hand 'as a principle of interpretation of IPR whereby one balances opposing interests' and on the other to 'rein-in IPR protection' 119 to account for societal impact. As Geiger has shown, a rights-based approach helps offset 'the overprotective tendencies of lobbydriven legislation'. ${ }^{120}$ This is, perhaps, a convincing explanation for the inclusion of IP following the Arab Spring.

110. Article 30 TRIPS.

111. Article 27(2) and (3) TRIPS.

112. Carlos María Correa, 'Implications of Bilateral Free Trade Agreements on Access to Medicines' (2006) 84(5) Bull.World Health Org. 399-404, 402 <https://www.ncbi.nlm.nih. gov/pmc/articles/PMC2627342/pdf/16710551.pdf >.

113. Article 4 Agreement between the Government of the United States of America and the Government of Tunisia <https://ustr.gov/sites/default/files/uploads/agreements/tifa/asset_ upload_file459_9936.pdf $>$.

114. Scientific Cooperation Agreement between the USA and Tunisia, August 15, 2014 $<$ https://www.state.gov/wp-content/uploads/2019/02/14-1209.2-Tunisia-Scientific-Cooperation. pdf>.

115. European Commission, Tunisia <http://ec.europa.eu/trade/policy/countries-and-regions/ countries/tunisia/>.

116. Article 38 Tunisian Constitution.

117. Article 18 Egyptian Constitution.

118. Ibid.

119. Jens Schovsbo, 'Constitutional Foundations and Constitutionalizing of IP Law - A Tale of Two Different Stories' (2015) 7(4) ZGE/IPJ 383-94, 383.

120. Christophe Geiger, "“Constitutionalising” Intellectual Property Law? The Influence of Fundamental Rights on Intellectual Property in the European Union' (2006) 37 Int'L.Rev. Intell.Prop.\&Competition.L. 390-97, 387. 
As IP legislation already existed, there was no need to allocate legislative power to the executive, as in the US Constitution. However, as a tool to introduce a balance favouring the right to health, constitutionalizing IP could address revolutionary demands. It would be consistent with international human rights law and the WTO's Doha Development Agenda. Paragraph 4 of the Doha Declaration states that members agree that 'the TRIPS Agreement ... should not prevent members from taking measures to protect public health'. ${ }^{121}$ Contrary to reality, the declaration also stated that TRIPS 'does not' impede such measures. ${ }^{122}$ The WTO emphasizes that IP is only one factor determining access to medicines ${ }^{123}$ but, where identified, negative effects of IP may be managed through constitutional balance.

\subsection{Intellectual property rights and human rights}

It was not until the twentieth century that IP transitioned from mere privilege, becoming part of the rights discourse through the United Nations Universal Declaration of Human Rights (UDHR). ${ }^{124}$ This status has had serious consequences. New technology attracts high IP rents, making the latest developments unaffordable for many consumers, especially in developing countries. The case of sofosbuvir, the first highly effective medication for Hepatitis C is illustrative. The prohibitive costs of sofosbuvir caused Egypt, with the 'highest prevalence rate in the world' ${ }^{125}$ potentially insurmountable problems. Government subsidies cannot accommodate such expensive drugs. Without cheap generic copies new treatments for life-threatening diseases are inaccessible for the vast majority. ${ }^{126}$ If IPRs are to fulfil their social function this problem cannot be ignored. A properly balanced human rights approach to IP is required. ${ }^{127}$

IPRs impede efforts to ensure the widest possible access to medicines. Until TRIPS, pharmaceutical products were commonly exempted from patent protection. Both Egypt and Tunisia exempted pharmaceutical products from patent protection prior to joining the WTO so generic copies of useful new drugs could be produced locally and sold cheaply, or imported. Since the TRIPS transition period expired this is impossible; pharmaceutical products must be patentable, ${ }^{128}$ putting IPRs in direct conflict with the right to public health. ${ }^{129}$

121. Doha WTO Ministerial Declaration on the TRIPS Agreement and public health 2001: TRIPS WT/MIN(01)/DEC/2 20 November 2001.

122. Ibid.

123. Intellectual Property Briefing: Current Issues in Intellectual Property: TRIPS and Public Health <https://www.wto.org/english/tratop_e/trips_e/trips_issues_e.htm>.

124. UN General Assembly, UDHR, 10 December 1948, 217 A (III).

125. Ahmed Elgharably et al., 'Hepatitis C in Egypt - Past, Present, and Future' (2016) 10 Int.J. Gen.Med, 1.

126. Issander Elamrani, 'Potent Properties' (2001) Business Monthly, American Chamber of Commerce Egypt <https://www.amcham.org.eg/publications/business-monthly/issues/8/ August-2001/1728/potent-properties $>$.

127. Hossam Bahgat and Rebecca Wright, 'Access to Medicines in Egypt: A Human Rights Approach to IP, Trade and Health' in Nagla Rizk and Lea Shaver (eds), Access to Knowledge in Egypt: New Research on Intellectual Property, Innovation and Development (Bloomsbury 2010) 56-91.

128. Article 27(1) TRIPS.

129. See eg Laurence R Helfer, 'Pharmaceutical Patents and the Human Right to Health: The Contested Evolution of the Transnational Legal Order on Access to Medicines' in Terence C Halliday and Gregory Shaffer (eds), Transnational Legal Orders (CUP 2015) 311-39 $<$ https://scholarship.law.duke.edu/faculty_scholarship/3426/>; also Article 25 UDHR 1948. 
Where IP protection is granted it must fulfil its part of the social bargain for the monopoly reward. Award of IPRs is essentially utilitarian, so a balanced human rights approach is entirely consistent. Justifications for IP based on natural law, which prioritize the interests of creators over those of the rest of society, are entirely unconvincing. Natural law justifications are promoted by those who benefit most. ${ }^{130}$ Even colonial champion John Locke saw the need for balance in a right to property created by labour, conceding that it must always be qualified where there is not "enough, and as good, left in common for others'. ${ }^{131}$ The United Nations Special Rapporteur in the field of cultural rights has highlighted that 'deprivations through patent exclusivity may be deemed as arbitrary, discriminatory or disproportionate', and rejects the idea of a human right to IP. ${ }^{132}$ As Drahos and Braithwaite put it, 'in any principled national legal system, basic human rights to health ... take precedence over (trump) utilitarian considerations'. ${ }^{133}$ In an even more vivid illustration of a similar, seemingly obvious point, "health care patents are not the same as patents for improvements to "toasters". ${ }^{134}$ While accepting that patent holders do have rights, they 'may also fairly be placed under a duty to deal, and a duty to act reasonably in their dealings, in the light of the subject-matter of their patent'. ${ }^{135}$ Thus, 'Human Rights law is emerging as a powerful countervailing influence', ${ }^{136}$ and the constitutional protection of IP should ensure that health does 'trump' IP where the right to health would otherwise be compromised.

\subsection{Islamic law and IP}

Largely due to colonial experiences of French occupation, both Egypt and Tunisia have civil codes based on a modified Napoleonic Code. However, both Egypt and Tunisia are Islamic countries, differentiating them from common and civil law jurisdictions, although the differences can be exaggerated. ${ }^{137}$ Today, Sharia has a special position in the Egyptian legal system. Egypt formally recognized this in 1971, stating that, 'Islam is the religion of the state, Arabic is its official language, and the principles of Islamic Sharia are a main source of legislation'. ${ }^{138}$ This was strengthened in 1980 with a constitutional amendment clarifying that Sharia is not merely ' $a$ ' main source of Egyptian law, but 'the primary source' of law. ${ }^{139}$ The 2012 Egyptian constitution, agreed under President Mohamed Morsi, amended the provision again, stating, 'the principles of Islamic Sharia are the principal source of legislation'. ${ }^{140}$ This change of emphasis was affirmed in 2014, in both the preamble and Article 3, which states,

130. Nachane (n 23) 257.

131. John Locke, 'Second Treatise of Government Chapter V "Of Property", Two Treatises of Government, Mark Goldie (ed) (J.M. Dent 1993) 127-40 section 26.

132. UN Human Rights Council Report of the Special Rapporteur on Cultural Rights Farida Shaheed, 4 August 2015 A/70/279 <https://documents-dds-ny.un.org/doc/UNDOC/GEN/N15/ 243/83/PDF/N1524383.pdf?OpenElement> at paras 87 and 90.

133. Drahos and Braithwaite (n 22) 200.

134. Vaver and Basheer (n 27).

135. Ibid.

136. Rochelle Dreyfuss and Cesar Rodriguez-Garavito (eds), Balancing Wealth and Health: The Battle over Intellectual Property and Access to Medicines in Latin America (OUP 2014) 343.

137. Lama Abu-Odeh, 'Who Cares About Islamic Law?' (2017) Al-Jumhuriya <https://www. aljumhuriya.net/en/authors/lama-abu-odeh>.

138. Article 2 Egyptian Constitution 1971.

139. Article 2 Egyptian Constitution 1971 (as amended in 1980).

140. Article 2 Egyptian Constitution 2012. 
as the 2012 constitution did, that 'Islam is the religion of the state and Arabic is its official language. The principles of Islamic Sharia are the principal source of legislation'. ${ }^{141}$ This means that all provisions in the constitution must be compatible with Sharia.

The compatibility of IP with Sharia is fairly well established. IP laws have existed throughout the Islamic world for decades, and many authors have explained its justification. ${ }^{142}$ Accordingly, IP protection is justifiable under Sharia as Heba Raslan's work, along with that of most, but not all, ${ }^{143}$ other scholars, has found.

Under the 2012 Egyptian constitution, the legislature was required to 'consult Al-Azhar on matters pertaining to Islamic law'. ${ }^{44}$ Al-Azhar University in Egypt, although frequently controversial, remains the leading Islamic institution on matters relating to Islamic law internationally. ${ }^{145}$ The necessity for judges to refer to Al-Azhar for authority was radical because previously judges were sole interpreters of law in the courts. Although the requirement for judges to consult Al-Azhar was removed in the 2014 constitution, the authority of Al-Azhar is still extremely important in Egypt and throughout the Islamic world.

Al-Azhar drafted a constitution, in 1979, intended as a template for Islamic countries to follow. Its influence is most evident in Egypt's 2012 constitution, but also present in the 2014 constitution. Notably, the Al-Azhar draft constitution protects 'freedom of ownership' in Article 39 and ascertains that 'an individual's ownership rights cannot be taken away unless it is for the public good' ${ }^{146}$ After the revolution in January 2011, Al-Azhar prepared further influential guidance on the future of Egypt, supplementing the draft constitution and specifically recommending a 'jurisprudence of priorities', which includes 'providing genuine health care' as a duty of the state. ${ }^{147}$

Al-Azhar played an important role in the post-revolution phase in Egypt, and actively addressed issues relating to knowledge and development. Grand Imam, Dr Ahmad el Tayyib encouraged 'Egyptians, Arabs, and Muslims to enter the competitive scientific and cultural arenas'. ${ }^{148}$ He expressed concern that 'the West was close to retaining all of scientific progress in its hands', and that 'it would have monopolized the march to science if not for the rise of Japan, China, India and Southeast Asia'. He looked to those jurisdictions as 'illuminating models for the Middle East's ability to break the monopoly and to embark into the age of science and knowledge'. ${ }^{149}$ Albeit obliquely, he seems to endorse a route to development that does not initially provide high levels

141. Article 2 Egyptian Constitution 2014.

142. Heba A Raslan, 'Shari'a and the Protection of Intellectual Property: The Example of Egypt' (2006-2007) 47 IDEA 497, 501.

143. As discussed in Qais Ali Mahafzah et al., 'The Perspective of Moral and Financial Rights of Intellectual Property in Islam' (2009) 23(4) ALQ 457-468.

144. Article 4 Egyptian Constitution 2012.

145. Al-Azhar University, 'Changing Structures of Islam', Oxford University <https://www. csia-oxford.org/al-azhar-university>.

146. Assem Hefny, 'Religious Authorities and Constitutional Reform: The Case of Al-Azhar in Egypt' in Rainer Grote and Tilmann J Roder (eds), Constitutionalism, Human Rights and Islam after the Arab Spring (OUP 2016) 116.

147. Ibid, 100.

148. Ahmad Al Tayyib, 'Constitutionalism, Human Rights and Islam after the Arab Spring' in Rainer Grote and Tilmann J Roder (eds), Constitutionalism, Human Rights and Islam after the Arab Spring (OUP 2016) 112-13.

149. Ibid. 
of IP protection. This would be consistent with the development history of other nowdeveloped countries, including the US.

The US was a 'leading IPR violator during the nineteenth century', ${ }^{150}$ with the US government supporting the acquisition of technical know-how by all means, fair or foul. The now-developed countries managed the process incrementally at a pace that suited their economies and local needs. Such countries, "profited from the lack of robust and full protection at the international level in order to copy ... technology from one another and disseminate it throughout their local industries'. ${ }^{151}$ Although the now-developed countries had over a century to adjust to increasing IP protection, ${ }^{152}$ in contrast, accession to TRIPS removed this possibility. Transitional periods for developing countries have been 'short and insufficient', with states expected to raise the IP bar rapidly, in a potentially inappropriate and damaging time-scale. In the case of Egypt, the greatest impact of WTO membership was predicted to come from IP. ${ }^{153}$ Egypt's once thriving pharmaceutical industry that 'contributed invaluably to public health' ${ }^{154}$ has had to make painful adjustments, with customers having 'to suffer a greater burden as drug costs increase without significant social benefits in return'. ${ }^{155}$

While IPRs are not generally considered contrary to Sharia, the exercise of IPRs may contravene Islamic principles in a number of possible ways. Monopolies are disapproved of if they cause harm. ${ }^{156}$ There is also the issue of excessive reward. Riba is a Sharia concept that applies to all economic activity and means that while a creator can expect a reasonable return on investment, the reward must not be excessive. ${ }^{157}$ The costs of producing medicines should account for research and development, but sometimes the disparity between costs and market price is shocking. Studies estimate production costs for the 12-week course of sofosbuvir at \$68-\$136, while the patented drug sold for $\$ 84000 .{ }^{158}$ Compared to production costs, the price is astronomically higher. ${ }^{159}$ Gilead, which did not develop the drug, but bought it from the original

150. Mike W Peng, 'History and the Debate Over Intellectual Property' (2017) 13(1) Manage. Organ.Rev. 15-38, 20; K Raustiala and C Sprigman, The Knockoff Economy: How Imitation Sparks Innovation (OUP 2012).

151. Ituku Elangi Botoy, 'From the Paris Convention to the TRIPS Agreement: A OneHundred-and-Twelve-Year Transitional Period for the Industrialized Countries' (2004) 7 JWIP $115-34,115$.

152. Ibid, 130.

153. Bernard Hoekman and Arvind Subramanian, 'Egypt and the Uruguay Round' (1996) Policy Research Working Paper 1597 (May 1996) The World Bank Europe and Central Asia and Middle East and North Africa Technical Department, Private Sector and Finance Team, 19 <https://elibrary.worldbank.org/doi/abs/10.1596/1813-9450-1597>.

154. Dina Iskander, 'TRIPS and Access to Medicines in Egypt' in Hans Lofgren and Owain David Williams (eds), The New Political Economy of Pharmaceuticals: Production, Innovation and TRIPS in the Global South (Palgrave 2013); Basma I Abdelgafar, The Illusive Trade-Off: Intellectual Property Rights, Innovation Systems, and Egypt's Pharmaceutical Industry (University of Toronto Press 2006).

155. Abdelgafar (n 154).

156. M Siddieq Noorzoy, 'Islamic Laws on Riba (Interest) and their Economic Implications' (1982) 14 Int.J.Middle East.Stud. 3-17, 9.

157. Ibid.

158. Swathi Iyengar et al., 'Prices, Costs, and Affordability of New Medicines for Hepatitis C in 30 Countries: An Economic Analysis' (2016) 13 PLoS Med 5.

159. Citing US Senators who wrote to Gilead for an explanation of the pricing, in Maurice Cassier, 'Between Financial Capitalism and Humanitarian Concerns: Value, Price and Profits of Hepatitis C Antivirals and Artemisinin-based Combinations Therapies for Malaria. The Making of 
developer did not make all the relevant information available to a US senate report; however, production costs 'were so small that some of Gilead's senior executives were not even aware of them'. ${ }^{160}$ Such a disparity between cost and price raises very serious questions about appropriate size of reward.

To offset criticism, Gilead entered into licensing agreements with developing countries, offering sofosbuvir at reduced prices. Such voluntary licences are cheaper, but remain too expensive for many governments and most individuals. More importantly, voluntary licensing agreements lack transparency and 'usually come with conditions' that constrain further measures to make the drugs available and more affordable. ${ }^{161}$

The potential for harm when medical treatment is unaffordable is strikingly clear. There is nothing currently in the IP system to prevent excessive reward, and the IPR monopoly means owners set the price, agreeing to license or not, and on what terms. This means the inequality is embedded.

Sharia contains the possibility of a strong exception in the public interest, through the principle of maslaha or istislah, which 'permits the jurist to find a solution using discretion that is based on determining and promoting [humanity's] best interest in a case'. ${ }^{162}$ Basma Abdelgafar explains that Sharia is fundamentally committed to 'the achievement of social justice ... understood as the equitable distribution of opportunities, wealth and privileges within a society in accordance with the fundamental principle of human dignity'. ${ }^{163}$ Property is an interest where maslaha clearly applies. ${ }^{164}$ Including IP in the constitution, along with the clear exhortation to act in accordance with Sharia, therefore empowers courts in Egypt, where necessary to avoid harm, to rule in the public interest using this doctrine. There are three tests to apply maslaha doctrine, which are that its application should not conflict with Sharia, there should be a genuine benefit, and it should benefit, not just an individual, but the wider community. ${ }^{165}$ Although some disagreement over the scope of this principle exists, ${ }^{166}$ the application of the above tests to the question of access to medicines would seem to be satisfied on all counts.

The Tunisian Constitution does not explicitly mention Islamic law in either the 1959 or the 2014 versions, although there are a great many references to Islam as the religion of the state. Article 1, Tunisian Constitution (2014), states that Islam is the state religion but, in contrast to Egypt, in Article 3, it states that 'Tunisia is a civil state based on citizenship, the will of the people, and the supremacy of law'. ${ }^{167}$ The decision not to refer to Islamic law in the constitution was highly contested but, ultimately, 'Tunisian constituents drafted a constitution that established

Pharmaceutical Value: Drugs, Diseases and the Political Economies of Global Health', Jean-Paul Gaudilliere, Kristin Peterson and Kaushik Sunder Rajan, June 2016, Paris, France, $7<$ https:// halshs.archives-ouvertes.fr/halshs-01375922/document>.

160. Ibid, 8.

161. Mohga Kamal Yanni, 'Hepatitis C Drug Affordability' (2015) 3 Lancet: Glob.Health 2 $<$ https://www.thelancet.com/journals/langlo/article/PIIS2214-109X(14)70365-1/fulltext>.

162. Siraj Sait and Hilary Lin, Land, Law and Islam: Property and Human Rights in the Muslim World (Zed Books 2006) 40.

163. Basma I Abdelgafar, Public Policy Beyond Traditional Jurisprudence: A Maqasid Approach (International Institute of Islamic Thought 2018) 23.

164. Majid Khadduri and Herbert J Liebesny, Law in the Middle East: Volume 1 Origin and Development of Islamic Law (MEI 1995) 101-2.

165. Sait and Lin (n 162) 40.

166. Khadduri and Liebesny (n 164) 101-2.

167. Article 3 Tunisian Constitution 2014. 
what they viewed as a modern and Muslim state', and 'although it did not include any mention of Sharia, made Tunisians part of what they saw as a Muslim community'. ${ }^{168}$ Thus, Sharia does have a role in Tunisian law but it is indirect rather than direct. In Tunisia, therefore, a different basis may be required to ensure that the balance between fundamental rights and IPRs is fair.

\section{THE TEXT OF THE IP CLAUSES IN THE EGYPTIAN AND TUNISIAN CONSTITUTIONS OF 2014}

The Egyptian Constitution contains 247 provisions, considerably longer than the 149 of the Tunisian Constitution. This physically illustrates the way in which 'national histories and experiences' shape the content, form and nature of different constitutions. ${ }^{169}$ It is important to note that in both Tunisia and Egypt the Arabic version is the official version. Translations are useful but unofficial.

The Egyptian Constitution protects IP in Article 69, a stand-alone article, in a section entitled Public Rights, Freedoms \& Duties, stating in the official Arabic version:

$$
\text { حمايتها القوانونية، و بنظم حقوق القانكية الفكرية بشتى أنو اعها فى كافة المجالات و تُشىء جهاز أ مختصاً لر عاية تلك الحقوق و }
$$

This is translated as: 'The State shall protect all types of intellectual property rights in all fields, and establish a specialized agency to uphold such rights and their legal protection as regulated by Law'. ${ }^{170}$

It seems strange to reference the creation of a supervisory body in the IP clause. However, Tunisia already has such an institution covering industrial property, something that is currently lacking in Egypt. The executive has always had the power to create such an institution in Egypt, but it has proved difficult, so creating a constitutional imperative may help achieve the goal. ${ }^{171}$ Better coordination of IP matters may produce more coherent policy, which not only protects IPRs but also addresses issues of social justice.

IP is protected in Article 41(2), Tunisian Constitution (2014), Part II, Rights and Freedoms. There is no reference to duties. The article covers property in general and specifies the limited instances where law may interfere with a property right. IP protection is in paragraph two of the property provision, stating simply: الملكية الفكرية مضنمونة

This is almost identical in structure and language to the way IP is protected and situated in the European Convention on Human Rights (ECHR), which itself is mirrored in the Charter of Fundamental Rights of the European Union (CFREU). ${ }^{172}$ Contained within the right to property more generally, and placed in a secondary paragraph, IP appears, therefore, to be covered by the limitations on the general right to property. Thus, the Tunisian provision differs from the Egyptian provision in its structure, its brevity and its language.

168. Malika Zeghal, 'Constitutionalizing a Democratic Muslim State without Shari'a: The Religious Establishment in the Tunisian 2014 Constitution' in Robert W Hefner (ed), Shari'a Law and Modern Muslim Ethics (IU Press 2016).

169. Robert Nozick cited in Mark Tushnet, Advanced Introduction to Comparative Constitutional Law (Edward Elgar Publishing 2018) 18.

170. Egyptian Constitution 2014 Part III.

171. Tushnet (n 109) 9.

172. Article 17 CFREU. 
An English translation of the Tunisian clause is, 'Intellectual Property is guaranteed'. This is a mere statement of fact. The same is true of the French and German versions of the, almost identical, Article 17 CFREU. ${ }^{173}$ It is only in the English version of Article 17 that the stronger wording 'Intellectual property shall be protected' appears, as Geiger has noted. Interpretation of this clause, therefore, depends on the language in which it is encapsulated. Geiger finds it curious that the maximalist policy of the European Commission seems to be based on the English approach, with the word 'shall' suggesting a mandate to strengthen IPRs that does not exist in French or German. ${ }^{174}$ There is no basis for such an interpretation in Tunisia, although Tunisia's deepening relationship with the EU may suggest convergence.

Geiger criticizes Article 17 CFREU for being both over-simplistic and 'ambiguous'. ${ }^{175}$ He slates the provision as 'badly drafted' ${ }^{176}$ and points out that, 'due to its atypical wording it is very difficult to have a clear understanding of the exact scope of this provision'. ${ }^{177}$ On the other hand, in separating IP from the rest of the property clause in the EU Charter, Geiger notes, positively, that the difference between IP and other forms of property is acknowledged, making it clear that IP is a more limited form of property that should be considered in light of its 'social function'. It may not only be Tunisia's close relationship with the EU, ${ }^{178}$ but also its keenness to embrace the social function of IP, that contributed to adopting a similar provision.

Although IP is found in documents under the heading of fundamental rights, only a strongly positivist reading would give IP such an elevated status. IP is not a true fundamental right. The basis for protection is clearly utilitarian and economic, as illustrated by EU Directive 2004/48 EC, which justifies it 'not only [on the basis of] promoting innovation and creativity, but also for developing employment and improving competitiveness'. ${ }^{179}$ The Directive 'respects the fundamental rights and observes the principles recognized in particular by the CFREU' ${ }^{180}$ which include the right to health 'at a high level'. ${ }^{181}$ Therefore, although the EU mandates 'full respect' ${ }^{182}$ for IP, a reasonable interpretation would add 'in so far as IP does not interfere unreasonably with other, more fundamental, rights'. This would also be consistent with the Tunisian provision. It is endorsed by the Advocate General of the Court of Justice of the European Union (CJEU), who has made it clear that IP law can be limited by fundamental rights, demonstrated through recent case law relating to conflict between Copyright and Freedom of Expression. ${ }^{183}$ Although there has been some

173. Christophe Geiger 'Intellectual Property Shall Be Protected!? Article 17(2) of the Charter of Fundamental Rights of the European Union: A Mysterious Provision with an Unclear Scope' (2009) EIPR 113, 115.

174. Ibid, 115.

175. Geiger (n 120) 3.

176. Geiger (n 173) 117.

177. Ibid, 113.

178. F Zardo and F Cavatorta, 'Friends Will Be Friends? External-Domestic Interactions in EUTunisia and EU-Morocco Security Cooperation after the Uprisings' (2018) International Politics. 179. Recital 1, DIRECTIVE 2004/48/EC of the European Parliament and of the Council of 29 April 2004 on the enforcement of intellectual property rights $<$ https://eur-lex.europa.eu/legalcontent/EN/TXT/?uri=CELEX\%3A32004L0048R\%2801\%29>.

180. Recital 32 EU Directive 2004/48 EC.

181. Article 35 CFREU.

182. Recital 32 EU Directive 2004/48 EC.

183. Geiger and Izyumenko (n 108) 132. 
resistance to this approach, it is, nevertheless, clear that an external limitation on IP is available in cases that concern the 'essence' of fundamental rights. ${ }^{184}$

The Egyptian constitution situates IP in a section that refers to duties as well as rights and freedoms. The duties are to society, therefore IPRs should benefit society. The provision states that it protects 'all types' of IP 'in all fields'. This would seem to be unnecessary when compared with the simplicity of the Tunisian provision. However, the provision mirrors the language of Article 27 TRIPS, demonstrating compliance with international obligations.

It is disappointing from a social justice perspective that neither the Egyptian nor the Tunisian Constitution 'dwells on the broader public policy objectives underpinning the protection of IPRS', ${ }^{185}$ or makes any direct reference to the purpose for IP protection, unlike the US Constitution, which expressly explains that IP protection is 'to promote the Progress of Science and useful Arts' ${ }^{186}$ To find the purpose requires reading the IP clause together with other constitutional provisions. Although the provisions are situated 'within a human rights framework', Abdel-Latif argues that this favours the IP rights holders, based on, either 'the rights of inventors and creators or the right to private property' ${ }^{187}$ It is important to note that rights holders are frequently not the original creators. The commercialization of inventions and creations mostly requires assignment or licensing to large corporations. Thus viewing IP as a human right for creators is often misleading. On the contrary, IP is a valuable economic right that must be balanced against fundamental human rights such as health, free expression, and food. These rights are also present in the Egyptian and Tunisian Constitutions and IPRs must be weighed against them.

Economic prosperity is undoubtedly important, and promoting a knowledge economy is a reason for including IP in the post-Arab spring constitutions, as Abdel-Latif (a former Egyptian diplomat with responsibility for international IP negotiations) clarified in 2014, immediately after the constitutions were agreed. He saw the decision to include IP as a mainly positive development, stating that 'for the first time in the history of these two countries, their new constitutions give high priority to building a knowledge economy and provide for the protection of intellectual property rights'. ${ }^{188}$ In his view, this addressed 'weaknesses that have characterized the national innovation system[s]', clearly signaling support for science and technological development. ${ }^{189}$ Whether the constitutional rhetoric is matched in reality will determine its success.

The Egyptian Constitution commits to Academic Freedom ${ }^{190}$ as well as Scientific Freedom. ${ }^{191}$ Freedom of Thought and Freedom of Research are protected in Articles 65 and 66 respectively, above the protection of IP. Article 23 states, 'The state grants the freedom of scientific research and encourages its institutions as a means to achieving national sovereignty, and building a knowledge economy'. The goal of building a knowledge economy is, thus, linked to achieving national sovereignty, something that suggests it is an aspiration yet to be realized. It signifies a continuing postcolonial

184. Ibid, 131.

185. Ahmed Abdel-Latif, 'Egypt and Tunisia Underscore the Importance of IP' (2014) WIPO Magazine <https://www.wipo.int/wipo_magazine/en/2014/04/article_0008.html>.

186. US Const. Section 1(8)(8).

187. Abdel-Latif (n 185).

188. Ibid.

189. Ibid.

190. Article 21 Egyptian Constitution.

191. Article 23 Egyptian Constitution. 
legacy. IP protection should, therefore, support Egyptian independence and not contribute to further international imbalance. This is relevant where public health is threatened due to the excessively high prices of medicines.

The Tunisian Constitution captures its spirit in the motto 'freedom, dignity, justice, and order'. ${ }^{192}$ The protection of health is vital for human dignity. Freedom of Expression is protected in the Tunisian Constitution in Article 31. Academic Freedom and Freedom of Scientific Research are protected in Article 33.

Both Egypt and Tunisia commit to funding science and technology in their Constitutions. Egypt has pledged 'at least $1 \%$ of the Gross National Product (GNP)'that will 'gradually increase to comply with international standards'. ${ }^{193}$ The Egyptian Constitution also explains that the 'State shall ensure effective means of contribution by private and non-governmental sectors and the participation of Egyptian expatriates in the progress of scientific research'. ${ }^{194}$ In the Tunisian Constitution, 'the state shall provide the necessary resources for the development of scientific and technological research'. ${ }^{195}$ These provisions all form part of an ambitious post-revolutionary strategy for regeneration, but it is unclear to what extent, if any, the inclusion of IP in the constitution contributes to these goals.

IP proponents claim that IP protection fosters creativity as well as enabling access to new knowledge that can help to resolve problems. A number of studies suggest, however, that IP benefits do not necessarily accrue without a strong research culture and infrastructure; even with a supportive research environment strong IPRs may be problematic. A culture capable of nurturing innovation 'is one in which innovation and creativity are valued and appreciated, adequately funded and channeled to specific needs' ${ }^{196}$ This requires both resources and political will. ${ }^{197}$ Where these are lacking IP may not be beneficial and 'stronger IPRs will not contribute to growth merely by being codified into laws'. ${ }^{198}$ Maskus, who is generally optimistic about the contribution of IP to developing countries, specifically in attracting foreign direct investment (FDI), ${ }^{199}$ nevertheless warns that 'IPRS could play either a positive or negative role in fostering growth and development', ${ }^{200}$ depending on conditions.

A convincing argument for promoting IP protection to develop a knowledge economy is that IP is the cheapest means of stimulating creativity. Rather than the state having to sponsor all innovative research, IP privatizes it. Individuals police it themselves and, where examination and registration are required, even the IP institutions pay for themselves through fees. It is also utilitarian in that most economically successful IP

192. Article 4 Tunisian Constitution.

193. Article 23 Egyptian Constitution.

194. Ibid.

195. Article 33 Tunisian Constitution.

196. Kamal Idris and Hisamitsu Arai, The Intellectual Property-Conscious Nation: Mapping the Path from Developing to Developed (WIPO 2008) <https://www.wipo.int/edocs/pubdocs/en/ intproperty/988/wipo_pub_988.pdf>.

197. See among others, Ian Hargreaves, Digital Opportunity: A Review of Intellectual Property and Growth (May 2011) <http://www.ipo.gov.uk/ipreview-finalreport.pdf> para 3.23, and Keith E Maskus, 'The Role of Intellectual Property Rights in Encouraging Foreign Direct Investment and Technology Transfer' (1998) 9 Duke J.Comp.\&Int'l.L128, 152.

198. Walter G Park and Juan Carlos Ginarte, 'Intellectual Property Rights and Economic Growth' (2007) 15 Contemp.Econ.Policy 51, 60.

199. Maskus (n 197) 152.

200. Keith E Maskus, 'Intellectual Property Rights and Economic Development' (2000) 32

Case West. Reserve.J.Int.Law 471, 502. 
monopolies are likely to be useful creations. IP rewards the creators - a happy balance if benefits are accessible to consumers. This 'cost consideration' was a reason for embracing IP when framing the US Constitution. ${ }^{201}$

However, Egypt and Tunisia are protecting IP at a much higher level than the US during its development stage, and for IP to fuel a knowledge economy, infrastructure such as adequate health care, nutrition, and education may need to be ubiquitous first. Otherwise, IP could even inhibit creativity and inventiveness. As Serageldine illustrated through her experience as managing partner of an IP law firm, the cost of acquiring a patent means that most Egyptian inventors cannot usefully engage with the IP system. The 'horrendous' costs of patent protection, makes it prohibitive for all but the very rich in Egypt, even with reduced fees at the international level for inventors from developing countries. In this way, a great deal of inventive potential could be lost. As she pointed out, 'inventors are not always rich'. ${ }^{202}$

Therefore, although developing a knowledge economy through additional IP protection sounds attractive, the contribution that constitutional protection makes, on top of already existing IP legislation, is unclear. Although this may change in the future, the majority of patents awarded in Egypt and Tunisia are to foreign applicants. ${ }^{203}$ Patents filed using the Patent Cooperation Treaty give an indication of states' international patenting activity. In 2017, for example, in the US residents filed 293904 patents and in the UK 13 301, compared with Egypt's 1025 and Tunisia's $172 .{ }^{204}$ While the figures show an increase in patenting activity in Egypt since 2014, the increase in patenting in Tunisia is negligible, and relative to more developed countries there is an enormous disparity.

Exports of manufactured goods are low. A study of Egypt, Tunisia, and Morocco found that despite transitioning to a more modern economic model earlier, subsequent 'deindustrialization' retarded development of more sophisticated technology in contrast to other states. ${ }^{205}$ In Tunisia and Egypt, in particular, this has been attributed to 'autocratic regimes and bad governance'. 206

Abdel-Latif's assessment of constitutional protection favouring IP rights holders is likely to please IP owners, but not consumers of IP-protected products, including medicinal products. This interpretation is not in the public interest and is unnecessary. The IP legislation protects IP owners' interests. Constitutional protection means that the public interest and fundamental rights must also be taken into account where IP protection is likely to them cause harm.

\section{SOUTH AFRICA: A DIFFERENT APPROACH}

Like Egypt and Tunisia, the South African Constitution did not previously protect IP prior to 1996 but the momentous events that ended the apartheid regime led to the radical

201. Walterscheid (fn 52) 34.

202. Serageldine (n 21).

203. 'Egyptian Patents Climb to 100 in 2017, Highest Number Since 2007' (2017) Al-Masry Al-Youm <https://egyptindependent.com/egyptian-patents-climb-to-100-in-2017-highestnumber-since-2007/>.

204. WIPO IP Statistics Data Center statistics database. Last updated December $2018<\mathrm{https} / /$ www3.wipo.int/ipstats/index.htm?tab=patent>.

205. Rim Ben Ayed Mouelhi and Monia Ghazali, 'Structural Transformation in Egypt, Morocco and Tunisia: Patterns, Drivers and Constraints' (2018) ERF Working Paper Series: Paper 1231, $17<$ http://erf.org.eg/wp-content/uploads/2018/10/1231-updated.pdf >.

206. Ibid. 
redrafting of the constitution. Interestingly, South Africa rejected calls to include IP in its constitution despite lobbying for IP to be 'entrenched in the Bill of Rights' ${ }^{207}$ Instead, South Africa chose to rely on a general property clause and other relevant provisions for the constitutional protection of IP. A challenge complaining that the absence of IP left the constitution deficient in its protection of, 'fundamental rights, freedoms and civil liberties' failed in the Constitutional Court. The South African Constitution is supreme, and IP proponents feared IP law would have to 'serve, and be true to, a superior lord and master', potentially weakening IPRs. ${ }^{208}$ Nevertheless, IP law in South Africa continues to operate, consistent with relevant treaties, including TRIPS, without express constitutional protection. However, it must comply with human rights obligations in the Constitution.

A South African IP policy document setting out its principles published in 2018 aims to 'advanc[e] a balanced and coordinated approach to IP that regulates IPRs in line with the South African Constitution'. While reassuring international partners of South Africa's commitment to treaty obligations, the policy states that South Africa will manage access to medicines more effectively and efficiently 'than the status quo currently allows'. ${ }^{209}$ This implies exceeding the very limited help provided by the WTO's Doha Decision, described as tedious and burdensome, ${ }^{210}$ highlighting the inadequacy of TRIPS flexibilities. The constitutional imperative of protecting health is stronger than the need to protect IP, particularly in emergency conditions, and justifies a more flexible response. In South Africa it has proved possible to use the Constitution in this way without a specific clause addressing IP.

\section{CONCLUSION}

Drafting a new constitution is usually an infrequent event and few will have prior experience of such an exercise. Mostly there will have been a period of turmoil, and the pressure to accommodate many competing agendas will, surely, be intense. IP has had a complex role historically and globally, which looks to continue as new regimes and constitutions emerge. The South African example has shown that it is not necessary to include IP in a constitution to balance IPRs against other fundamental rights. However, as this paper argues, including IP in a constitution, rather than merely adding to IP owners' already weighty rights, offers a potential solution to difficulties created by systematic imbalance. Following Geiger's analysis, 'fundamental rights' could 'be the very instruments to guarantee a certain flexibility in IP law',211 and to re-introduce the social function of property.

As Stiglitz said, 'How we regulate and manage the production of knowledge and the right of access to knowledge is at the center of how well ... the knowledge

207. Owen H Dean and Mabel M Jansen, 'The Constitution and Intellectual Property' (2014) Advocate $33<$ https://www.sabar.co.za/law-journals/2014/august/2014-august-vol027-no2pp32-36.pdf $>$.

208. Ibid, 33.

209. Department of Trade and Industry, Republic of South Africa, 'Intellectual Property Policy of The Republic of South Africa, Phase I' $27<$ http://www.thedti.gov.za/news2018/ IP_Policy2018-Phase_I.pdf>.

210. Abbas and Riaz (n 13) 45.

211. Geiger (n 120) 9. 
economy ... works and ... who benefits'. ${ }^{212}$ It remains to be seen what impact increased protection will have for countries such as Egypt and Tunisia. Whether constitutional protection for IP will prove a major factor in fuelling a knowledge economy is unclear, but the impact on the general public, whose interests could be sublimated, may be substantial. Whilst including IP as a constitutional provision appears to strengthen the property rights of IP owners, it may also be a means of limiting them by balancing them against other constitutionally protected rights, providing greater scope for courts to rule in the public interest. This would mean additional protection for the interests of stakeholders (other than the rights holders) not available in the IP legislation alone, which is interpreted only in terms of its internal exclusions and limitations. This alternative reading may be what was intended in the Egyptian and Tunisian contexts, and so support the aims of 'bread, freedom, social justice and human dignity'. 